\title{
Rare metastasis to the iris from renal cell carcinoma responds to an anti-angiogenic therapy - a case report
}

\author{
Linda Mahjoubi ${ }^{1}$, Jennifer Marie-Louise ${ }^{2}$, Harold Merle ${ }^{2}$, Vincent Molinié ${ }^{1}$ \\ 1. Department of Pathology, University Hospital Center of Martinique, France. 2. Department of Ophthalmology, \\ University Hospital Center of Martinique, France.
}

Correspondence: Linda Mahjoubi. Address: Department of Pathology, University Hospital Center of Martinique, France. E-mail: linda.mahjoubi@gmail.com

Received: August 11, 2014

DOI : $10.5430 /$ crcp.v2n1p80
Accepted: September 26, 2014

URL: http://dx.doi.org/10.5430/crcp.v2n1p80

\section{Abstract}

A 73-year-old Afro-Caribbean man with pulmonary metastatic renal cell carcinoma presented to the ophthalmological department for decreased visual acuity, blurry vision and photophobia. Initial ocular examination revealed a $5 \mathrm{~mm}$ mass located to the iris. Cerebral magnetic resonance imaging (MRI) revealed a contrast enhancing lesion in the cerebellum measuring $5 \mathrm{~mm}$, without surrounding edema. The iris mass was excised during cataract surgery. Histological examination of the mass revealed a clear cell proliferation and immunohistochemical analyses revealed a typical phenotype of clear cell renal cell carcinoma with expression of vimentin, CD10 and p504s. The final diagnosis was a metastatic clear cell renal cell carcinoma. A systemic treatment with sunitinib, a tyrosine kinase inhibitor of vascular endothelial growth factor receptor (VEGF) receptor pathway, was introduced with a good safety profile and six months follow up revealed no ophthalmic recurrence and stabilization of the pulmonary and cerebellum metastasis.

\section{Key words}

Kidney neoplasms, Neoplasms metastasis

\section{I ntroduction}

Renal cell carcinoma represents $3 \%$ of all adult cancers ${ }^{[1]}$. The peak incidence is in the sixth decade, more frequently in men ${ }^{[1]}$. Clear cell renal cell carcinoma accounts for approximately $80 \%$ of renal cell carcinoma ${ }^{[1,2]}$. Ocular metastases from renal cell carcinoma are rare and typically involve in the iris, ciliary body, choroids, eyelid, lacrimal sac and the orbit $^{[3-7]}$. Herein, we presented a case of iris metastasis from renal cell carcinoma, rare site of metastasis.

\section{Case report}

To evaluate the extension of a prostatic cancer on a patient, a computed tomography (CT) was performed and incidentally revealed an enlarging left renal lesion with multiple pulmonary masses for which he refused any treatment. One year later, he presented to our hospital and complained of neurologic disorders such as headaches, decreased visual acuity, blurry vision and photophobia. Initial ocular examination revealed a $5 \mathrm{~mm}$ tumor located to the iris. Cerebral magnetic resonance 
imaging (MRI) detected a contrast enhancing lesion in the cerebellum measuring $5 \mathrm{~mm}$, without surrounding edema. Cataract surgery and excision of the lesion were performed (see Figure 1). Histological examination revealed a clear cell proliferation (see Figure 2), and immunohistochemical analyses revealed a typical phenotype of clear cell renal cell carcinoma with expression of vimentin, CD10 and p504s (see Figure 3, 4). The final diagnosis was an iris clear cell renal cell carcinoma metastasis. A systemic treatment with sunitinib, a tyrosine kinase inhibitor of vascular endothelial growth factor receptor (VEGF) receptor pathway, was introduced with a good safety profile and six months follow up revealed no ophthalmic recurrence and stabilization of the pulmonary and cerebellum metastasis.

Figure 1. Hematoxylin and eosin stain. Iris cells are hyper pigmented. Neoplastic proliferation is characterized by the proliferation of clear cells. Original magnification $\times 40$

Figure 2. Hematoxylin and eosin staining demonstrates clear cells with abundant clear cytoplasm and atypical basophilic nuclear. Magnification $\times 200$

Figure 3. Immunohistochemical stain. Vimentin is positive in the membrane and cytoplasm of neoplastic renal cells. Magnification $\times 400$

Published by Sciedu Press
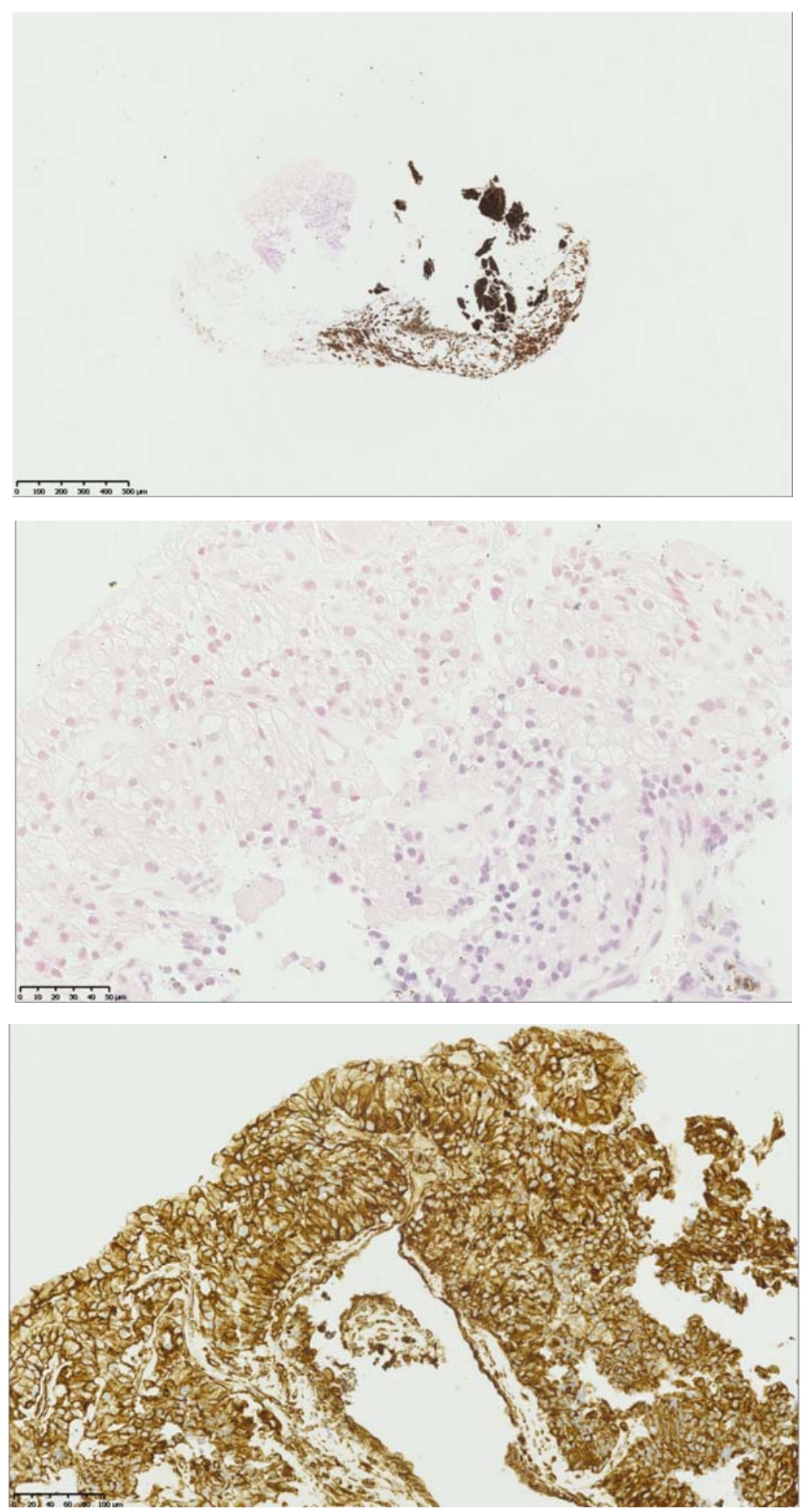
Figure 4. Immunohistochemical stain. P504S is positive in the membrane of neoplastic renal cells. Magnification $\times 200$

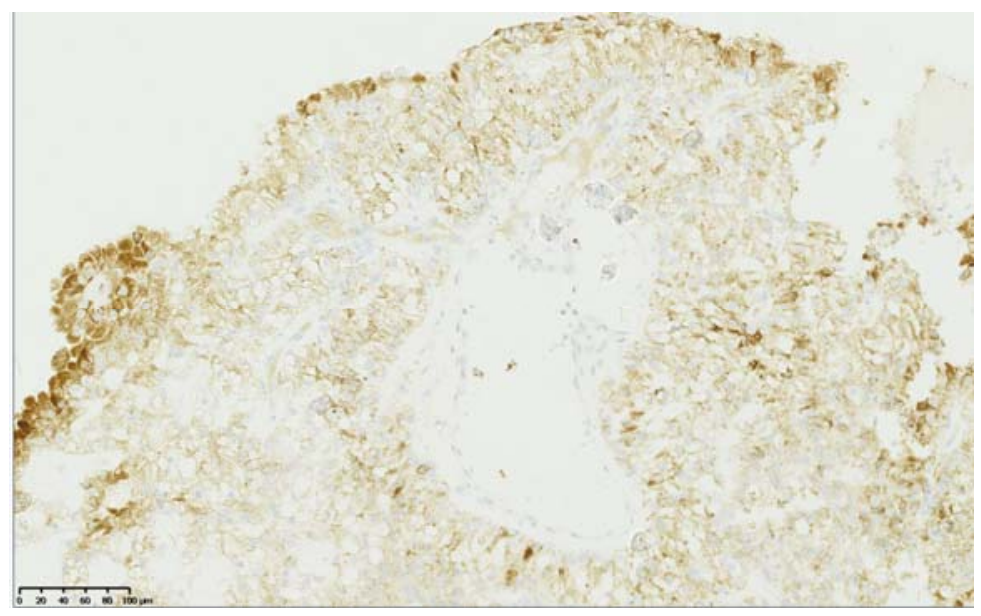

\section{Discussion}

Ocular metastases from renal cell carcinomas are rare, less than 25 reports have been published ${ }^{[3-8]}$. Sountoulides et al. presented a review of 19 cases with orbital metastasis from renal cell carcinomas ${ }^{[6]}$. The ophthalmological symptommatology depends on the localization of the metastasis. Most of the patients complained of proptosis, diplopia, eye vision difficulties, cataract, upper lid tumor or epiphora. In most of the cases, there was a history of renal cell carcinoma. In only seven cases, the ocular metastasis was the first manifestation of a previously unknown renal cell carcinoma.

The clinical diagnosis of ocular metastasis is usually suspected in the context of metastatic renal cell carcinoma. Most of the patients have been treated by surgery and adjuvant therapy such as alpha-interferon systemic immunotherapy or external beam radiation therapy; intravitreal injections of bevacizumab or proton beam radiotherapy ${ }^{[4,5,8]}$.

Our case is the first case reported with anti-angiogenic treatment sunitinib, an anti-VEGFR tyrosine kinase. VEGF-targeted therapies with humanized anti-VEGF monoclonal antibody (bevacizumab) combined with interferon (IFN)- $\alpha 2 \mathrm{a}^{[9]}$ or anti-VEGFR tyrosine kinases (sunitinib ${ }^{[10]}$, pazopanib ${ }^{[11]}$ ) are recommended in first line treatment for good and intermediate prognosis patients with metastatic renal cell carcinomas ${ }^{[12]}$. In second line, in case of resistance with first line anti-VEGFR, an inhibitor of mammalian target of rapamycin (mTOR) is usually proposed.

Receptor tyrosine kinases like VEGFR play a role in the pathogenesis of clear cell renal cell carcinomas though involvement of the von Hippel-Lindau (VHL) gene ${ }^{[10]}$. In normal cells, VHL prevents the formation of HIF, hypoxia inducible factor, which normally activates angiogenic factors. Mutations in VHL if found in $80 \%$ of renal cell carcinomas. The accumulation of HIF overexpresses VEGF which contributes to the tumor's angiogenesis and growth. Antiangiogenic therapies are effective in renal cell carcinoma and our case is the first showing good result of use of antiangiogenic therapy in renal cell carcinoma with iris metastasis.

\section{Author contributions}

LM had full access to the patient data and wrote the first draft. VM helped to gather the data and reviewed the final draft. JML was the ophthalmologist resident who examined the patient. HM was the ophthalmologist who did the surgical excision of the lesion. All authors have read and approved the final manuscript.

\section{References}

[1] Comperat E, Camparo P. Histological classification of malignant renal tumours at a time of major diagnostic and therapeutic changes. Diagn Interv Imaging. 2012; 93(4): 221-231. PMid: 22465787. http://dx.doi.org/10.1016/j.diii.2012.01.015 
[2] Cohen HT, McGovern FJ. Renal-cell carcinoma. N Engl J Med. 2005; 353(23): 2477-2490. PMid: 16339096. http://dx.doi.org/10.1056/NEJMra043172

[3] Hammad AM, Paris GR, van Heuven WA, et al. Spontaneous regression of choroidal metastasis from renal cell carcinoma. Am J Ophthalmol. 2003; 135(6): 911-913. http://dx.doi.org/10.1016/S0002-9394(02)01973-6

[4] Kurli M, Finger PT, Schneider S, et al. Eyelid-sparing adjuvant radiation therapy for renal cell carcinoma. Ophthalmologica. 2006; 220(3): 198-200. PMid: 16679797. http://dx.doi.org/10.1159/000091766

[5] Shome D, Honavar SG, Gupta P, et al. Metastasis to the eye and orbit from renal cell carcinoma-a report of three cases and review of literature. Surv Ophthalmol. 2007; 52(2): 213-223. PMid: 17355859. http://dx.doi.org/10.1016/j.survophthal.2006.12.004

[6] Sountoulides P, Metaxa L, Cindolo L. Atypical presentations and rare metastatic sites of renal cell carcinoma: a review of case reports. J Med Case Rep. 2011; 5: 429-1947-5-429.

[7] Ware GT, Haik BG, Morris WR. Renal cell carcinoma with involvement of iris and conjunctiva. Am J Ophthalmol. 1999; 127(4): 460-461. http://dx.doi.org/10.1016/S0002-9394(98)00357-2

[8] Alasil T, Khazai B, Loredo L, et al. Renal cell carcinoma metastasis to the ciliary body responds to proton beam radiotherapy: a case report. J Med Case Rep. 2011; 5: 345-1947-5-345.

[9] Escudier B, Pluzanska A, Koralewski P, et al. Bevacizumab plus interferon alfa-2a for treatment of metastatic renal cell carcinoma: a randomised, double-blind phase III trial. Lancet. 2007; 370(9605): 2103-2111. http://dx.doi.org/10.1016/S0140-6736(07)61904-7

[10] Motzer RJ, Hutson TE, Tomczak P, et al. Sunitinib versus interferon alfa in metastatic renal-cell carcinoma. N Engl J Med. 2007; 356(2): 115-124. PMid: 17215529. http://dx.doi.org/10.1056/NEJMoa065044

[11] Sternberg CN, Davis ID, Mardiak J, et al. Pazopanib in locally advanced or metastatic renal cell carcinoma: results of a randomized phase III trial. J Clin Oncol. 2010; 28(6): 1061-1068. PMid: 20100962. http://dx.doi.org/10.1200/JCO.2009.23.9764

[12] Albiges L, Choueiri T, Escudier B, et al. A Systematic Review of Sequencing and Combinations of Systemic Therapy in Metastatic Renal Cancer. Eur Urol. 2014. http://dx.doi.org/10.1016/j.eururo.2014.04.006 